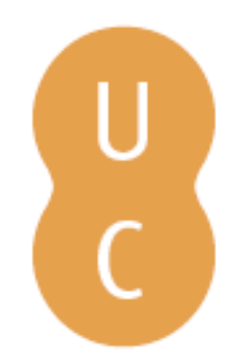

\title{
pกmpalina
}

\section{Debaixo de fogo: a música em tempo de guerra}
Autor(es):
Barbosa, Maria Augusta
Publicado por: Imprensa da Universidade de Coimbra
URL persistente:
URI:http://hdl.handle.net/10316.2/30033
DOI:
DOl:http://dx.doi.org/10.14195/978-989-26-0567-8_3

Accessed : $\quad$ 26-Apr-2023 11:34:10

A navegação consulta e descarregamento dos títulos inseridos nas Bibliotecas Digitais UC Digitalis, UC Pombalina e UC Impactum, pressupõem a aceitação plena e sem reservas dos Termos e Condições de Uso destas Bibliotecas Digitais, disponíveis em https://digitalis.uc.pt/pt-pt/termos.

Conforme exposto nos referidos Termos e Condições de Uso, o descarregamento de títulos de acesso restrito requer uma licença válida de autorização devendo o utilizador aceder ao(s) documento(s) a partir de um endereço de IP da instituição detentora da supramencionada licença.

Ao utilizador é apenas permitido o descarregamento para uso pessoal, pelo que o emprego do(s) título(s) descarregado(s) para outro fim, designadamente comercial, carece de autorização do respetivo autor ou editor da obra.

Na medida em que todas as obras da UC Digitalis se encontram protegidas pelo Código do Direito de Autor e Direitos Conexos e demais legislação aplicável, toda a cópia, parcial ou total, deste documento, nos casos em que é legalmente admitida, deverá conter ou fazer-se acompanhar por este aviso.

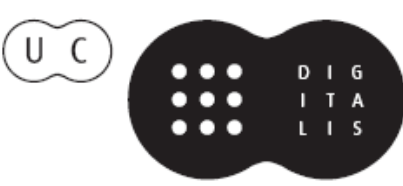




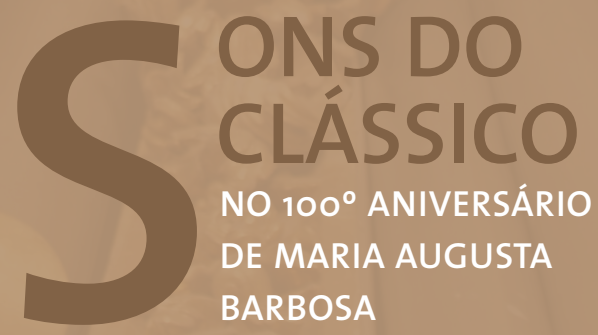

J. M. Pedrosa Cardoso

Margarida Lopes de Miranda COORDENAÇÃO 
Maria Augusta Barbosa

\section{DEBAIXO DO FOGO: \\ A MÚSICA EM TEMPO DE GUERRA ${ }^{2}$}

O início da 2. ${ }^{a}$ Grande Guerra em Setembro de 1939 levou-me a pensar ser prudente voltar a Portugal e aguardar aqui o seu primeiro desenrolar.

Em Novembro desse mesmo ano, porém, regressei a Berlim e facilmente me adaptei a um estudo absorvente no início de uma guerra ainda relativamente calma, evidente apenas no racionamento inteligentemente elaborado e obrigatoriamente seguido, além de alguns bombardeamentos nocturnos, durante os quais os estrangeiros, ao contrário dos nacionais, não eram obrigados a recolher aos abrigos.

Aproveitei portanto essas vigílias forçadas para avançar no estudo das novas matérias e preparar os trabalhos marcados, entre os quais as longas transcrições de paleografia musical.

As aulas seguiam sempre com absoluta regularidade, mesmo após noites de um bombardeamento que se prolongava até quase de manhã.

Quando estabelecimentos de géneros alimentícios haviam sido atingidos pelos bombardeamentos dessa noite, a rádio indicava muito cedo, na manhã seguinte, quais os estabelecimentos congéneres próximos em que deviam ir fornecer-se os cidadãos que estavam inscritos nos estabelecimentos danificados.

De resto, a vida seguia normalmente, fiel às suas habituais realizações artísticas e culturais, expressas em concertos, óperas, conferências e representações teatrais.

\footnotetext{
2 Final de um auto-retrato, pelos vistos incompleto, ditado no remanso da Casa de Saúde e Repouso da Amoreira, (Ramada-Odivelas) à fiel "secretária" Sónia de Carvalho. Título nosso.
} 
Era porém indispensável a maior prudência em conversas ou simples trocas de impressões. Uma palavra menos cautelosa, uma insignificante apreciação pessoal de desacordo poderia levar à cadeia, se fosse considerada pela Gestapo adversa à doutrina política em vigor.

A espionagem podia estar em toda a parte, mesmo entre as camadas dos estudantes, que podiam nem sempre o ser. E não se sabia nunca se as críticas que alguns ousavam fazer sobre a situação sócio-política do momento eram sinceras ou se eram uma forma de anzol superiormente orientado.

A perseguição religiosa - católica ou protestante - era um facto habitualmente camuflado; e digo camuflado, porque estas duas correntes de fé eram forças demasiadamente poderosas na Alemanha, contra as quais a autoridade não ousava investir claramente; mas fazia-o em surdina.

$\mathrm{E}$ assim nasceu, nesse tempo de guerra, a missa vespertina ao entardecer de sábado, com validade de missa dominical.

Eu própria li, nessa manhã dum domingo de Inverno, de cuja data exacta me não recordo, o aviso afixado à porta da igreja fechada, no qual a autoridade eclesiástica local transmitia, à comunidade católica, a ordem recebida do governo alemão que proibia a celebração da missa antes das onze horas, sempre que um bombardeamento inimigo se tivesse prolongado para além das 24 horas de sábado; a seguir, no mesmo aviso, vinha também a notícia da concessão pontifícia da validade dominical da missa vespertina acima referida.

Estava solucionado o problema que havia sido posto ao católico praticante alemão: ou faltar à missa dominical não cumprindo o seu dever de católico ou renunciar à necessidade legítima de usar do único dia mensal de folga concedido neste tempo de guerra a todo o trabalhador alemão, para escassas horas de um passeio ao ar livre. E não se esqueça que se estava no Inverno, em que em grande parte da Alemanha o sol se põe pelas 15 horas.

Afastar os fiéis da prática religiosa era afastá-los suavemente da acção da igreja. E a igreja, tendo disso a percepção, deu a resposta adequada acatando a ordem.

Problema dominante na Alemanha de Hitler, mesmo já antes da guerra, era a comunidade judaica.

O ódio ao judeu tinha raízes fundas, reforçadas pela política nacional-socialista hitleriana, no seu objectivo de consolidar, projectar a nação alemã 
e, nela, de elevar económica e culturalmente o nível da grande massa popular. Abriam-se assim, à "Força pela Alegria", as grandes salas de óperas, teatros, bailados e concertos, organizavam-se excursões culturais ou de simples lazer, dedicavam-se-lhe conferências acessíveis mas de nível.

O judeu, com a sua tendência inteligentemente organizadora, detinha na Alemanha, aquando da subida ao poder de Hitler, fortes polos de medicina, de direito, de arte e sobretudo do alto comércio. A colaborar nas suas fileiras ele atraía de preferência os seus correligionários, ficando em princípio para segundo plano os alemães de raça ariana, por vezes forçados, por necessidade de sobrevivência, a ocupar, com preparação técnica idêntica, lugares subalternos em instituições dominadas por judeus alemães.

E o ódio nasceu. Um dia, no Outono de 1938, vi serem destruídas, à pedrada, montras de lojas de luxo, que soube depois serem propriedade de comerciantes judeus. O povo assistia com calma.

No dia seguinte, era a vez das sinagogas, incendiadas de norte a sul do país. Vi em chamas a mais importante sinagoga de Berlim. Algum tempo depois, a autoridade comunicava pela rádio que as destruições e incêndios haviam sido expressão espontânea do povo alemão. Claro, ninguém acreditou.

A perseguição violenta aos judeus, na sua dupla forma de escravatura no trabalho imposto e de tortura conducente à morte, era conhecida do povo alemão, embora nem sempre na horrível violência das suas modalidades; mas ele nada, absolutamente nada, podia fazer. E todavia alemães houve - soube-o confidencialmente - que haviam ajudado judeus, com risco muito sério da própria liberdade e vida.

De um professor universitário soube eu, mais tarde, ter conservado escondido em sua casa, até ao fim da guerra, com perigo de vida para si e toda a família, o filho de um amigo judeu.

A dona e vendedeira de um pequeno lugar de legumes e fruta disse-me em segredo esconder por hábito alguma fruta e legumes até pelas 18 horas, para que os pudessem adquirir amigos seus judeus, proibidos que estavam de fazer compras antes dessa hora; e a essa hora, tudo estaria já esgotado.

Têm-se vindo a fazer críticas cerradas ao Papa por não ter levantado a voz então perante os crimes cometidos. Mas podia e devia tê-lo feito? 
Em face do fanatismo cerrado que dominava os nacional-socialistas, particularmente concentrados na Gestapo, cujo dever consistia principalmente em manter coeso o pensamento nacional em todo o país, uma palavra de desaprovação teria bastado para despoletar sobre a igreja e sobre os católicos, na Alemanha e nos países ocupados, um ódio de consequências imprevisíveis.

Nas camadas intelectuais com que convivi, eram evidentes o descontentamento e o medo do futuro, um e outro mantidos cautelosamente no silêncio. Mas nem por isso se deixava de por vezes tomar decisões altamente perigosas, apenas do conhecimento dos amigos em quem se confiava.

Também neste caso estava a Livraria Buchholz, em Berlim, que nas suas instalações e em salas habilmente camufladas, reunira e salvara da destruição iminente telas de alto valor da pintura dos séculos 19 e 20, com os quais me foi possível dar um passo mais na apreciação da arte nesse tempo contemporânea.

Neste ambiente vivi, estudei e concluí uma licenciatura, com uma alimentação reduzida é certo, mas suficientemente regulada, perante um aumento crescente de bombardeamentos em intensidade e duração, que se estendiam agora às horas do dia como às da noite.

Em 13 de Agosto de 1943, pude regressar a Lisboa no último comboio que passou em Nürberg umas duas ou três horas antes de a cidade ter sido completamente destruída. 